\title{
A Disgrace to the Master Race: Colonial Discourse Surrounding the Incarceration of "European" Prisoners within the Colony of Natal towards the End of the Nineteenth and Beginning of the 20th Centuries
}

\section{P.E.R}

Pioneer in peer-reviewed, open access online law publications

Author

Stephen Allister Peté

Affiliation

University of KwaZulu-Natal South Africa

Email PETE@ukzn.ac.za

Date published

8 December 2017

Editor Prof C Rautenbach

How to cite this article

Peté SA " A Disgrace to the Master Race: Colonial Discourse Surrounding the Incarceration of "European" Prisoners within the Colony of Natal towards the End of the Nineteenth and Beginning of the 20th Centuries" PER / PELJ 2017(20) - DOI

http://dx.doi.org/10.17159/17273781/2017/v20i0a3011

\section{Copyright}

\section{DOI}

http://dx.doi.org/10.17159/17273781/2017/v20i0a3011

\begin{abstract}
The discourse surrounding the punishment of offenders within a society reveals much about the particular ideological underpinnings of power within that society. Penal discourse within colonial societies is particularly interesting in that it traces the specific contours of the racist ideologies which characterise those societies. This article is focused upon penal discourse within the Colony of Natal towards the end of the nineteenth and beginning of the twentieth centuries. Within the colony at this time, the race of an offender was becoming increasingly important in determining the type of punishment, treatment and training considered appropriate for that offender. This article is focused - in particular - upon the discourse surrounding the punishment of "European" offenders in colonial Natal. It is submitted that the punishment of these offenders raised all sorts of ideological problems for the colonists, since the offenders in question were members of the white "master race". The following central themes within the colonial penal discourse of the time are discussed: first, the role that "shame" and "degradation" were considered to play in the punishment of white - but not black - prisoners; second, the perceived need to train white - but not black - prisoners in skilled work, to enable white prisoners to find employment upon leaving prison; and, third, the perceived need to keep white - but not black - prisoners out of the public gaze, in particular avoiding situations in which white prisoners could be seen being punished alongside black prisoners and subject to the control of black prison guards. Examining the precise contours of the penal ideology which underpinned the punishment of offenders in colonial Natal may be useful in understanding certain of the foundations of racist penal thinking during subsequent periods of South African history, including the notorious apartheid era.
\end{abstract}

\section{Keywords}

Apartheid; colonial; colony; discourse; discrimination; ideology; imprisonment; offenders; Natal; penal; prisoners; prisons; punishment; race; racial. 


\section{Introduction}

Much has been written about the savage punishments inflicted upon the indigenous peoples of Africa by European colonisers. ${ }^{1}$ Vicious corporal punishment was an expression of colonial sovereignty, power and authority. The beatings inflicted upon colonised peoples reflected not only the might of the coloniser - but also "ownership" on the part of the coloniser over the colonised:

Because its roots are essentially authoritarian, the imposition of corporal punishment is ... an exercise of sovereignty. White sovereignty in colonial Natal, for example, was expressed in the lash marks on the backs of countless black offenders. Beating an offender or a naughty child expresses not only anger, but also 'ownership' over the person being beaten ... It serves to confirm the established patterns of power and authority which exist in a given (usually authoritarian) society or relationship. ${ }^{2}$

The colonial obsession with corporal punishment may be explained by two deeply ambiguous impulses within the colonial psyche: racist fear on the one hand, and racist paternalism (a twisted kind of "love") on the other:

[C]olonial societies in Africa were motivated by two opposing impulses. The one impulse was fear of the surrounding indigenous peoples, who almost always greatly outnumbered the colonists. The other impulse was a racist paternalism which caused the colonists to regard the indigenous peoples as children requiring guidance and correction. When it came to punishment, each of these two opposing impulses reinforced the other in its support for corporal punishment as the ideal form of punishment for African offenders. On the one hand, such offenders were regarded as dangerous savages, who would only respond to physical pain. On the other hand, African offenders were seen as being simple and childlike, and therefore amenable to physical correction. ${ }^{3}$

If harsh physical correction was considered by colonial society to be the ideal form of punishment for colonised (black) Africans - what about the other side of the coin? What forms of punishment should apply to members of the (white) colonial community who happened to step out of line? The punishment of "European" offenders raised all sorts of ideological problems for the colonists, since the offenders in question were members of the white "master race". Within the colonial context, the punishment of this group of

* $\quad$ Stephen Allister Peté. BA LLB (University of Natal) LLM (University of Cape Town) M Phil (University of Cambridge) PhD (University of KwaZulu-Natal). Associate Professor of Law, School of Law, University of KwaZulu-Natal, South Africa. Email: PETE@ukzn.ac.za.

1 See, for example: Bernault "Politics of Enclosure" 15; Killingray "Punishment to Fit the Crime?" 106-110; Read "Kenya, Tanzania and Uganda" 109; Peté 1986 Natal U L \& Soc'y Rev 102; Peté and Devenish 2005 JSAS 3-21; Peté "Brief History of Human Rights in the Prisons of Africa" 48-50.

2 Peté 1998 SAJHR 436.

$3 \quad$ Crocker and Peté 2007 Obiter 271. 
offenders took on a much greater ideological significance than their small numbers might, at first blush, have implied.

The purpose of this article is to examine elements of colonial discourse towards the end of the nineteenth and the beginning of the twentieth centuries, concerning the incarceration and punishment of "European" prisoners in the Colony of Natal. As is pointed out in this article, the overall shape and distinctive contours of this particular area of colonial penal discourse are clearly distinguishable from the penal theories, beliefs and opinions surrounding the punishment of "non-European" prisoners in the Colony of Natal at this time. A central contention of this article is that any proper understanding of the penal ideology of colonial Natal must start with an acknowledgement of the centrality of race in determining the type of punishment, treatment and training considered appropriate for a particular inmate. The manner in which colonial penal discourse is shaped by attitudes to race becomes particularly apparent in discussions concerning the treatment of white prisoners in the Colony of Natal.

This article begins with an examination of certain of the ideological, political and economic underpinnings of the racist attitudes which characterised much of white settler discourse in colonial Natal. The deep roots and broad parameters of Victorian racial ideology are discussed, as are the specific social, political and economic conditions which underpinned the particular racist attitudes of many of the white settlers in the colony. Following this broad discussion of the roots of racism in colonial Natal, the sections which follow examine several themes central to the discourse surrounding the punishment of white prisoners in particular. Among the themes discussed are: First, the significant emphasis within colonial penal discourse on the role of "shame" and "degradation" in the punishment of white prisoners. ${ }^{4}$ Second, the perceived need to train white prisoners - but not black prisoners - in skilled work, to enable white prisoners to find employment upon leaving prison. ${ }^{5}$ Third, the anxiety within colonial penal discourse over

$4 \quad$ The "shame" and "degradation" arose - allegedly - because the penal system of the colony was not completely segregated, which meant that white prisoners were sometimes forced into contact with black prisoners and black prison guards. A good example of the perceived importance of "shame" in the punishment of white prisoners is found in the following statement of the Resident Magistrate of Durban: "To White prisoners the exposure of having to appear in public amongst the Convict Gang is a greater punishment than any labour inside the walls of the Gaol could be." See NAB (KwaZulu-Natal Archives Pietermaritzburg Repository) CSO (Colonial Secretary's Office, Natal) 314/2265: Report of Assistant Resident Magistrate Durban, 8 October 1868.

5 Since the economy of colonial Natal was divided along strict racial lines, with all nonskilled labour being performed by "non-Europeans", it was argued that white 
the wider political and ideological implications of allowing white prisoners to be seen being punished alongside black prisoners, as well as being subject to the control of black prison guards. ${ }^{6}$

\section{Victorian racial theory in the context of a colonial economy in transition}

Colonialism and imperialist exploitation were justified and rationalised by Victorian racial theory. For example, Herbert Spencer's doctrine of Social Darwinism supposedly provided a "scientific" basis for the view that the Anglo-Saxon civilisation was the culmination of the evolutionary process. ${ }^{7}$ It was the philanthropic duty of the white race to uplift the degraded coloured races, which were seen as being on a lower plane of evolution and civilisation.

In addition to the broad influence of Victorian racial ideology, local factors also contributed to the overall shape of the racist attitudes specific to many white colonists in Natal. The white settler community in the colony was small and insular. This insularity was reinforced by an ever-present fear of being overwhelmed and wiped out by the indigenous Zulu people - who vastly outnumbered the white colonists. The colonists regarded the Zulu people as being particularly warlike and savage, which led to constant fear and anxiety within the small white colonial community. ${ }^{8}$ These feelings of fear and anxiety were combined with deep feelings of racial superiority, linked to the Victorian idea - discussed in the previous paragraph - that it was the duty of the white race to bring the light of "civilisation" to the "dark

prisoners needed to be taught skills while in prison, if they were to stand any chance of getting employment when they were released.

6 Despite being prisoners, white inmates in colonial Natal remained members of the ruling white settler elite, which meant that their treatment - even while in prison was highly symbolic. A good example of the perceived wider ideological ramifications of allowing white prisoners to be punished by black prison guards can be found in the following opinion expressed in the Legislative Council of the Colony of Natal on 24 August 1883, after a white prisoner was whipped by a black guard for attempting to escape: "[T]here can be no greater means of bringing the governing race into contempt than to allow a coloured man to whip a white man, even though he be a prisoner under confinement." See the Debates of the Legislative Council of the Colony of Natal 1883 vol 6 Debate of 24 August 1883: Mr Crowder.

7 See Riekert Natal Master and Servant Laws 15.

$8 \quad$ With a large African population internal to the colony and the unconquered Zulu military state to the north, the white colonists felt themselves to be constantly under threat - surrounded on all sides by savage barbarians who were capable of launching an attack at any time. Respect for white authority had to be maintained at all costs and defiance of such authority met with immediate and severe retribution. This element of fear within white racist ideology profoundly affected theories of punishment in the colony. 
continent". 9 These deeply ambivalent impulses within the white colonial psyche - insecurity and fear mixed with arrogance and paternalism - served as mutually reinforcing mechanisms which isolated the white settler community of colonial Natal and turned it in upon itself. It is thus unsurprising that white settlers would dread being rejected by and isolated from the white community. As discussed in detail later in this article, this helps explain why the colonists regarded the "shame" and "degradation" of being imprisoned together with black prisoners as being such an important factor in the punishment of white prisoners.

Apart from the factors discussed above, racist ideology in colonial Natal towards the end of the nineteenth and the beginning of the twentieth centuries cannot be fully understood without an appreciation of the seismic political and economic shifts that were taking place within the colony at this time. Within the context of a predominantly agricultural economy, these shifts may be described, in general terms, as part of a transition from a precapitalist to a capitalist mode of agricultural production. In his classic work Race and State in Capitalist Development, Stanley Greenberg points to two different routes that may be taken in the transition from pre-capitalist to capitalist agriculture. The one route would follow what Greenberg calls the "English Example", while the other would follow the "German Example". Greenberg ${ }^{10}$ describes the latter route as involving the "plundering of the peasantry", which requires the construction of "labor-repressive machinery". According to Greenberg: 11

The commercial farmers in Germany made the transition to capitalist agriculture not by abandoning feudalism, but by restoring feudal rights and dues and placing severe restrictions on the mobility of farm laborers. For an extended period the farmers, faced with expanded agricultural markets, demanded increased state vigilance over the labor market ... [T]he landowners, while increasingly responsive to market opportunities, retained their distinctive, "feudal" guise during an extended transition to capitalist agriculture.

The route to capitalist agriculture followed in colonial Natal resonates strongly with the "German Example" expounded by Greenberg. This transition did not mark an end to but rather an entrenchment of pre-capitalist

9 As David Welsh states, the Victorian imperialists were convinced of the "superiority of their own culture over indigenous native cultures" (see Welsh Roots of Segregation 27). Note further that the term "Dark Continent" was, it is thought, first used in print by the American explorer and journalist Henry Morton Stanley in his work Through the Dark Continent published in 1878 (see Stanley Through the Dark Continent).

10 Greenberg Race and State in Capitalist Development 56, 57.

11 Greenberg Race and State in Capitalist Development 58. 
colonial modes of racial domination and control within the colony. As Greenberg ${ }^{12}$ points out:

\begin{abstract}
It is a reasonable presumption that dominant landowners in a racial order, if they followed the German example, would seek to extend and perhaps elaborate the traditional labor system and the racial disabilities associated with it. The need to expand production of cash crops would be met, not by the rapid displacement of rural labor and the resort to labor markets, but by a threepronged plundering of the subordinate peasantry: first, by further restricting subordinate landholding and, consequently, subsistence production; second, by intensifying subordinate labor services, and third, and most important, by increasing state control over the movements of subordinate farm laborers.
\end{abstract}

In colonial Natal, as the transition from pre-capitalist to capitalist forms of agricultural production began to gather pace towards the end of the nineteenth century, the obsession of the colonists with race seemed, if anything, to grow stronger rather than weaker. This fits with Greenberg's point that, within the context of a racial order, continued patterns of racial domination could play an important part in the "plundering of the subordinate peasantry":

Dominant landowners ... make the transition to capitalist agriculture by underlining the role of race in the society and labour market. For landowners, the race lines are so intimately associated with their access to the state and their control over rural labourers as to be indistinguishable from them ... [D]uring an extended transition to capitalist agriculture, dominant landowners would remain a distinctive and powerful remnant of the precapitalist period, insisting on the elaborated state role in the labour market and insisting on the racial order itself. ${ }^{13}$

A racial order certainly existed in colonial Natal and racial domination was intimately connected to a system of labour coercion and exploitation within the colony. ${ }^{14}$ This point is useful in helping to understand the roots of the racial prejudices which were so much part of the ideological make-up of the white settlers in the colony. The colonial state was too weak to destroy the strong and prosperous African peasantry. Thus the white settlers were forced to look to a coercive labour system based upon racial lines rather than to the creation of a class of labourers subject only to the control of market forces. The coercive nature of social relations between whites and blacks in colonial Natal had a profound effect upon ideologies of punishment within the colony. Frustration at the shortage of labour amidst a large indigenous African population, as well as the desire to preserve a raciallybased coercive labour system clearly contributed to rampant racism within

12 Greenberg Race and State in Capitalist Development 58, 59.

13 Greenberg Race and State in Capitalist Development 59.

14 A strident racist ideology was deeply entrenched in the collective psyche of white colonial Natal. See, for example, Marks Reluctant Rebellion 3-26. 
the ranks of Natal's white colonists. For black offenders, this meant excessive exposure to harsh "sanguinary" punishments - often in the form of whippings carried out with the notorious "cat-o-nine-tails" - designed to subjugate the indigenous population through fear and physical pain. ${ }^{15}$ For white offenders, as will be seen in the sections which follow, it meant something else entirely.

\section{A divergence in penal ideology - the colony vs the mother country}

It is instructive to compare and contrast the penal ideology which was dominant in Britain with that which was dominant in Natal during the period under examination. British society was based upon the idea of formal equality. The penal system of the "mother country" was designed to convince each individual prison inmate of his guilt and to induce him to "reform" himself, so that he could resume his place within the "social consensus". ${ }^{16}$ The social, political and economic system of colonial Natal, however, was based upon white colonial domination and was designed to emphasise white colonial sovereignty. In terms of the ruling ideology, offences committed by the indigenous peoples were an attack on the colonial status quo. Any attack on white authority by a black offender was to be met with swift, severe and uncompromising punishment. White offenders, on the other hand, had to be punished separately from black offenders in order to retain the appearance of a strong, unified front separating the coloniser from the colonised. The only manner in which white prisoners could be rehabilitated - it was thought - was through completely separate punishment designed to reintegrate these prisoners into white colonial society. The precise manner in which it was thought appropriate to punish white offenders will be discussed in greater detail in the sections which follow.

A consequence of the divergence in ideology discussed in the previous paragraph is worth noting. As may be expected, discussion of the

15 The white colonists in Natal were so insistent that the notorious "cat-o-nine-tails" was indispensable in the punishment of black offenders that the 1906 Natal Prison Reform Commission referred to the widespread whipping of offenders in the colony as the "Cult of the Cat". See GN 344 in Natal GG of 5 June 1906: Report of Prison Reform Commission para 70. Also see Peté 1986 Natal U L \& Soc'y Rev 102-106. As Ignatieff states in relation to the emergence of the punishment of imprisonment in Britain: "The key problem for social order ... was to represent the suffering of punishment in such a way that those who endured it and those who watched its infliction conserved their moral respect for those who inflicted it. The efficiency of punishment depended on its legitimacy." See Ignatieff Just Measure of Pain 72. 
appropriate type, manner and severity of punishment to be applied in the colony often gave rise to conflict between the colonists and the colonial authorities. On the one hand the Imperial Government constantly urged penal reform upon the colonists, in order to bring Natal's penal system in line with the model adopted in the colonial metropole, which was regarded as accepted penal practice. On the other hand, the colonists of Natal, swayed by their strident racist ideology, complained bitterly that imprisonment had no effect on the ignorant and idle "Kafirs", and attacked what they regarded as misguided sentimentalism on the part of the Imperial authorities. In the middle of this ideological conflict stood the colonial state, forced to carry out the directions of the Imperial Government, but at the same time confronted with the reality of Natal's social, political and economic orientation. This was often an uncomfortable position to occupy. In its efforts to tone down the harshest punishments, in order to bring Natal more in line with "accepted penal policy", the colonial state was faced with implacable opposition from the political representatives of the colonists. ${ }^{17}$ In the tug-of-war between the Imperial authorities on the one hand and the colonists on the other hand, the balance of power rested initially with the Imperial Government, which exercised ultimate authority over the direction of penal policy. Thus, during the first part of the colonial period from 1845 until the granting of responsible government status to Natal in 1894, British influence over penal policy was particularly marked. This began to change, however, during the latter part of the colonial period, from 1894 until 1910. During this latter period, the interests and preoccupations of the colonists came to the fore and began to dominate penal policy. ${ }^{18}$ Calls for strict racial separation within the penal system became increasingly strident during this period.

\section{White unemployment, the gratuity system and institutions to aid white ex-prisoners}

The fact that the economy of colonial Natal was structured along racial lines, forming an interrelated system of labour coercion and exploitation, meant that unskilled manual labour was carried out by blacks, whereas skilled

17 A good example of opposition by colonists to any reduction in the severity of punishments meted out to black offenders was their response to the proposed abolition of the whipping of "servants" for civil offences in 1850. For an account of this attempt by the colonial state to abolish the punishment of whipping under the Master and Servants Ordinance Bill 9 of 1876, "To Alter and Amend the Ordinance No 2, 1850", entitled "Ordinance for Regulating the Relative Rights and Duties of Masters, Servants and Apprentices"; see Peté and Devenish 2005 JSAS 5-6. 
labour was reserved for whites. This in turn meant that, if a white prisoner was to stand any chance of finding employment upon his release, he had to possess some sort of skill because he could not rely on finding a job as an unskilled labourer. ${ }^{19}$ This was a problem which was to become particularly pronounced towards the end of the nineteenth and the beginning of the twentieth centuries, as the number of white prisoners in the Colony of Natal began to increase. The realisation on the part of the authorities that the lack of employment for white ex-prisoners was becoming an ever bigger problem is indicated by the introduction of the "gratuity mark system" into the prisons of colonial Natal in 1884. This system was to be applicable to "European" prisoners only. In August of that year, it came to light that small gratuities were paid by the Public Works Department to prisoners who were skilled tradesmen and were employed as such on public works. ${ }^{20}$ There were no formal rules regulating the practice, however, and the Acting Colonial Secretary noted that it seemed wrong that a distinction should be made between skilled and unskilled labour. ${ }^{21}$ The Colonial Engineer agreed that a formal system should be instituted, but stated that:

European prisoners only should be eligible for this gratuity as Natives leaving prison do not labour under the same disabilities as Europeans with regard to obtaining employment or a means of livelihood. ${ }^{22}$

As will be shown subsequently, this argument was used extensively by the prison reformers at the turn of the century. The Colonial Secretary approved a formal system of granting gratuities to European prisoners, and stated that:

[T] he introduction of a system of marks, to be applicable in the case of European prisoners of long sentence, would prove very beneficial, as the circumstance that men are discharged from Gaol unprovided with means of any kind frequently induces fresh crime..$^{23}$

19 A good example of the difficulties encountered by white ex-prisoners in obtaining employment upon being discharged from prison in the Colony of Natal is to be found in the following statement made in the Legislative Council of the Colony about this problem: "Let that man seek employment where he is known. Will he obtain it? No. Everyone shuns him, and his only place is in the society of criminals." See Debates of the Legislative Council of the Colony of Natal 1883 vol 6 Debate of 24 August 1883: Mr Crowder 324.

$20 \quad$ NAB CSO 982/3976.

21 NAB CSO 982/3976: Acting Colonial Secretary to Colonial Engineer, 25 August 1884.

22 NAB CSO 982/3976: Colonial Engineer to Colonial Secretary, 25 August 1884.

23 NAB CSO 982/3976: Colonial Secretary to Governor, 2 September 1884. 
The Executive Council approved of a system of marks being instituted, ${ }^{24}$ and regulations were drawn up and published in the Government Gazette of 2 December $1884 .{ }^{25}$ Despite a resolution by the Durban Gaol Board that the mark system be extended to "Natives and Indians", 26 it was restricted to "European" prisoners sentenced to one year and upwards, when employed on public works. Marks would be allotted on a daily basis for actual work performed, and the gratuity awarded to a prisoner at the end of his term would depend on the number of marks accumulated. However, the maximum gratuity to be awarded was not to exceed the sum of three pounds sterling. The Superintendent would have the power to deprive a prisoner of a certain number of marks for any breach of prison discipline, and a prisoner re-convicted for a third time was not eligible to participate in the system. This system was in no way to interfere with the mark system for remission of sentence. ${ }^{27}$

Although activities like tailoring, mat making and carpentering were not "public works", these too were to be covered by the mark system. In the Government Gazette of 5 June 1885 the rule was amended to cover not only "public works" but also "such other works of such nature as the Governor may approve". ${ }^{28}$ In this same Gazette, authority was also given to make the system applicable to military prisoners. ${ }^{29}$ Although the system was initially applicable only to "European" prisoners in the strict sense of the word, in 1888 it was extended to include "coloured" prisoners of "European" descent. The Resident Magistrate of Pietermaritzburg stated that these men were "in many instances, the most valuable workers in the Gaol". ${ }^{30}$ The Government thus decided to accept a resolution of the Pietermaritzburg Gaol Board in February 1888, that:

... all those prisoners of European descent mentioned in the Ration Scale [i.e. Eurasians, natives of St Helena and the Cape (excluding Kafirs), American Negroes, French Creoles, and West Indians] ... should participate in the gratuity [system].$^{31}$

The gratuity mark system was designed to provide "European" prisoners with funds upon their being discharged from prison, which would tide them

$24 \quad$ NAB CSO 982/3976: Clerk Executive Council to Colonial Secretary, 6 September 1884.

$25 \quad$ GN 436 in Natal GG of 2 December 1884.

$26 \quad$ NAB CSO 982/3976: Meeting Durban Gaol Board, 20 October 1884.

$27 \quad$ GN 436 in Natal GG of 2 December 1884.

$28 \quad$ GN 161 in Natal GG of 5 June 1888 (amended).

$29 \quad$ GN 161 in Natal GG of 5 June 1888 (amended).

$30 \quad$ NAB CSO 1180/614: Residential Magistrate Pietermaritzburg, February 1888.

$31 \quad$ NAB CSO 1180/614: Meeting of Pietermaritzburg Gaol Board, 7 February 1888. 
over until they were able to obtain suitable employment. However, it was not until the end of the nineteenth and the beginning of the twentieth centuries, that institutions were established to assist white ex-prisoners. In July 1895, a Society was formed in Durban to establish a Home for the temporary relief of discharged white prisoners. Although established primarily to aid discharged prisoners, the Home was also to assist the unemployed and others in need. ${ }^{32}$ At this time, the unemployment problem was becoming increasingly acute. For example, the Superintendent of Police in Durban reported as follows in April 1897:

It will be necessary to devise some plan to cope with the unemployed. Last night I had not room in the Casual Ward for all, and had to allow some to sleep in an empty cell. ${ }^{33}$

One of the main functions of "The Durban Home" was thus to assist discharged inmates to obtain suitable employment. The Governor of the Durban Gaol stated as follows in his report for the year 1896:
A system has been adopted during the year whereby, through the kindness of an institution called 'The Durban Home', European convicts on discharge from gaol are assisted in obtaining some sort of employment to keep them from destitution, as is the custom in vogue at English gaols. ${ }^{34}$

In 1897 suitable premises were obtained at 65 Stanger Street, adjacent to the Gaol, and an ex-officer in the Salvation Army was appointed Superintendent of the Home. ${ }^{35}$ In the same year the Society petitioned the Government for a grant of funds to assist in the running of the Home, and stated, inter alia, that:

... a large number of Discharged Prisoners have been received into the Home, for whom food and shelter have been provided, and in many cases employment found. ${ }^{36}$

The government authorities approved a grant of $£ 100$ for "The Durban Home" for the year 1897-98. ${ }^{37}$ In 1900 the Salvation Army approached the government for assistance in establishing a Home for discharged white prisoners and other needy cases. This Home was to operate in conjunction

32 NAB CSO 1518/2324: Honorary Treasurer Durban Home to Colonial Secretary, 30 March 1897.

33 Durban Corporation Superintendent of Police Report Book 6: Report of Superintendent, 26 April 1897.

$34 \quad$ Natal Blue Book 1896 at F44: Report of Governor Durban Gaol, para 5.

35 NAB CSO 1518/2324: Honorary Treasurer Durban Home to Colonial Secretary, 30 March 1897.

$36 \quad$ NAB CSO 1518/4040: Petition No 20 of 1897, 5 May 1897.

37 NAB CSO 1518/4040: President and Treasurer Durban Home to Principal Under Secretary, 15 November 1899. 
with a "Social Farm", as was the practice in Cape Town, and the government was asked to provide a piece of land in the vicinity of Durban for the establishment of such a farm. ${ }^{38}$ The Attorney General reacted very positively to these requests by the Salvation Army, and stated that:

It concerns the welfare of the State to assist in the redemption of those who have been prisoners in its Gaols and who on leaving prison are naturally very heavily handicapped, and in many cases find it exceedingly difficult to get employment. ${ }^{39}$

While the government decided not to grant any land to the Salvation Army, it was willing to authorise a grant-in-aid for the establishment of a Receiving Home for discharged white prisoners. A sum of $£ 300$ was thus inserted, for this purpose, in the Estimates for the year 1902.40 The Salvation Army was eventually able to obtain a piece of land of approximately 30 acres on the Natal south coast, which became known as the "South Coast Rescue Farm". ${ }^{41}$

\section{Increasing white unemployment and agitation for a separate industrial prison for whites}

During the first few years of the twentieth century the problem of unemployment among whites in the Colony of Natal became increasingly severe, as is revealed by the following statements which appeared in the annual reports of the Superintendent of Police in Durban:

1902: [T]he Borough being full of Europeans out of employment, I sincerely hope that the authorities will disband the irregulars in the new country ... ${ }^{42}$

1903: At present there are 150 Europeans of all trades out of work, who have registered their names for employment at the Corporation Office. ${ }^{43}$

1904: I am sorry to find that we have in Durban about 290 able bodied Europeans of various trades registered at our Bureau as out of employ ... .44

38 NAB CSO 1685/9488: Commissioner Salvation Army to Attorney General, 19 November 1900.

$39 \quad$ NAB CSO 1685/9488: Attorney General to Colonial Secretary, 26 November 1900.

$40 \quad$ NAB CSO 1685/9488: Attorney General to Commissioner Salvation Army, 9 January 1907.

41 NAB CSO 2847/Evidence of Peter Stuivenga, Ensign, Salvation Army, 11 October 1905.

42 Durban Corporation Superintendent of Police Report Book 6: Report of Superintendent 5 June 1902.

43 Durban Corporation Superintendent of Police Report Book 7: Report of Superintendent, 5 December 1903.

44 Durban Corporation Superintendent of Police Report Book 7: Report of Superintendent, 1 January 1904. 
At this time, most urban centres in South Africa were experiencing similar problems. Johnstone notes that at around the turn of the century many whites were forced off the land by various circumstances, including the extension of large-scale commercial farming, the severe rinderpest epidemic of 1896, and the devastation and upheaval caused by the South African War. ${ }^{45}$ Bundy states that: "Natal's ... increasingly urbanised white population rose from 46,000 in 1891 to 97,000 in $1904 \ldots$...46 The white unemployment problem could not be solved by employing whites at unskilled jobs, since these were performed by cheap black labour. Thus, as was pointed out at the beginning of this section, a white ex-convict who did not possess work skills would not be able to find employment in Natal and would be forced to re-enter a life of crime. This point was well illustrated by the Natal Witness, in commenting on a proposal to separate white from black prisoners, and to employ the former in agricultural labour:

To teach a European the duties of an agricultural labourer in this country might be of passing benefit to the prison authorities, while he was with them, but neither the convict himself nor the society to which he must return when liberated would be much the better. There is no opening for white agricultural labourers here, and the only thing that will elevate the prisoner and improve his position in the world will be the acquirement of a trade by which he can earn an honest livelihood as soon as his sentence has expired. ${ }^{47}$

The above was part of a campaign conducted in 1904 by the editor of The Natal Witness, F. Horace Rose, which was aimed at bringing about prison reform in the Colony of Natal. The campaign opened with an article written by Rose entitled A Plea for the Criminal, and was to end with the appointment of the Prison Reform Commission of 1905-1906. ${ }^{48}$ A central issue in the campaign was to be the treatment of white prisoners in colonial Natal.

Rose's initial article put forward two broad theories criticising the penal system of the time - particularly as it related to white prisoners. First, the

45 Johnstone Class, Race and Gold 52-53.

$46 \quad$ Bundy Rise and Fall of the South African Peasantry 185.

$47 \quad$ The Natal Witness "Prison Reform" (29 December 1904). A similar point was made by Mr TCC Sloane, General Secretary of the YMCA in Natal, who drew attention to the differences in the employment situation in England as opposed to Natal: "In the large cities at Home missions and societies existing for the betterment of the people have one great advantage, in that they are able to obtain employment requiring no previous knowledge for men whom they are seeking to raise. Many prisoners are, of course, 'skilled' men; but even these when discharged are willing to take anything, and out here the 'anything' is done to such an extent by the kafir and the Indian that a greater difficulty is created." See The Natal Advertiser "Employment Bureau for Ex-Convicts" (3 June 1904).

48 The Natal Advertiser "A Plea for the Criminal" (30 May 1904). 
criminal instinct was seen as a disease which could be cured by sympathetic treatment. Second, it followed from this that punishment should improve the criminal rather than degrade or harden him. Rose stated that the penal system did, in fact, harden and degrade the prisoner rather than improve him. He saw imprisonment as being characterised by a monotonous, demoralising routine of futile labour:

Punishment by means of barren labour is the be-all and end-all of the gaol today. 49

According to Rose the "routine of gaol life - its galling severity, its degrading toil, its hopeless and well-nigh unsupportable monotony" dehumanised long-term prisoners and reduced them to the level of mere machines. ${ }^{50}$ The useless nature of the work performed (i.e. stone breaking) was also seen as having a demoralising effect "on any man capable of turning to profitable account his hands and head". ${ }^{51}$ Apart from causing psychological degradation, the harsh labour resulted in the physical deterioration of longterm prisoners. Rose ${ }^{52}$ stated:

\section{I have heard, and I can well believe it, that seven years imprisonment with hard labour is sufficient to bring mental and physical ruin on the strongest man; and I believe it is a fact that very few Europeans live to complete a longer term than ten years.}

However, it was not only the individual prisoner who suffered but also society as a whole. First, the work performed by prisoners had no economic value and did not repay society for the cost of administering the prisons. Second, prisoners who had undergone long terms of imprisonment were physically and morally unfit to re-enter society on their release. This resulted in a high rate of recidivism, and one prison official to whom Rose spoke estimated that over $50 \%$ of discharged criminals who had served long terms gravitated back to the gaols. In place of the harsh system of crushing penal labour, Rose proposed the establishment of an industrial prison "in which provision is made for the practise of every useful occupation by which the enforced labour of the convict may be turned to practical account". ${ }^{53}$ Prisoners who knew a trade would practise that trade, and new trades would be taught. In addition, there would be educational instruction in various 
fields of study. Of course, it was white and not black prisoners whom Rose had in mind when making this proposal.

The establishment of the industrial prison proposed by Rose would provide the solution to both the ideological and material economic problems related to the reform of the white prisoner in Natal. First, it would ensure the separation of white from black prisoners, "since an institution of this description would open up a field for the labour of white convicts into which it would be impossible, at all events for some time to come, for natives to intrude". ${ }^{54}$ Second, it would provide the necessary training in skilled work for its inmates:

Here we would have, in place of the stone yard, well-equipped workshops of every description, for the use of carpenters, blacksmiths, tailors, wheelwrights, bootmakers - in fact an industrial Whiteley's, at which almost everything a man can fashion with his hand and brain would be made. ${ }^{55}$

The proposed establishment of an industrial prison was made possible by the very fact that it was to be restricted to a small percentage of Natal's prison population. Rose ${ }^{56}$ noted:

\begin{abstract}
We have, comparatively speaking, only a small European criminal population here - it is on the Europeans the experiment would have to be tried first, the treatment of native criminals being considered later. With the comparatively few White prisoners we have, it would be possible, at a minimum of expenditure to establish an industrial prison which would pay for itself within a very few years.
\end{abstract}

Rose claimed further that Natal could lead the "civilised" world in prison reform - since there was only a small "civilised" (ie white) community in Natal. He stated that:

Natal is the country, par excellence, where such an experiment could be tried with the best prospects of success ... It is a problem which must be faced sooner or later by civilised communities. The large ones will find it overwhelmingly difficult to grapple with until, perhaps, a small one, more favourably situated for the experiment, solves it for them by practical demonstration. ${ }^{57}$

$54 \quad$ The Natal Advertiser "Testimony from Within" (1 June 1904).

55 The Natal Advertiser "A Plea for the Criminal" (30 May 1904). Also see The Natal Witness "Why Waste Prison Labour?" (8 June 1905) and The Natal Witness 6 May 1905 "The City Gaol".

56 The Natal Advertiser 30 May 1904 "A Plea for the Criminal". Also see: The Natal Witness 8 June 1905 "Why Waste Prison Labour?", and The Natal Witness "The City Gaol" (6 May 1905).

57 The Natal Advertiser "A Plea for the Criminal" (30 May 1904). Also see The Natal Witness "Why Waste Prison Labour?" (8 June 1905) and The Natal Witness "The City Gaol" (6 May 1905). 
Natal would not only serve as an example for overseas countries, but would also show the way for the rest of South Africa. On 29 December 1904 the Natal Witness expressed the wish that a system of industrial prisons conceived in Natal would in the future "embrace the whole of the Colony and of South Africa". 58

Hand-in-hand with a programme of industrial training for white prisoners, Rose $^{59}$ saw it as essential to introduce a system of "indeterminate sentences":

Acceptance of the principle on which indeterminate sentences are based practically embraces that which underlies prison industrialism, both aiming at the reform of the criminal in almost the same way. The indeterminate sentence places on the criminal the responsibility for his incarceration and prison industrialism gives him the where withal for discharging it.

In other words, the purpose of the industrial prison was to reform the criminal by training and educating him in habits of industry. This being so, the prisoner should remain in prison until it appeared that he had been sufficiently trained and educated - so as to enable him to lead an honest and respectable life. This principle could also be expressed by equating crime with a disease of which a prisoner had to be cured before he could be released. To liberate a prisoner before he had been reformed was seen as irrational:

As well might we liberate the raving madman because he has been a year in the asylum, or turn the sick out of the hospitals because they have been there a week!60

Of course, a system of indeterminate sentences would give the prison authorities absolute power over the lives of their prisoners. Each prisoner would have to conform to the norms laid down by the authorities or remain in prison indefinitely. Indeed, this was seen as one of the major advantages of the system, since the prisoner was made responsible for his own fate:

The length of his incarceration depends practically upon himself: upon his conduct, his willingness to learn, his ability to perform; and upon such evidence of reformation as may be demanded of him by the authorities... ${ }^{61}$

Essentially it was sought to gain control over the prisoner's mind - i.e. ideological control. It was only once the prisoner had convinced himself of

\footnotetext{
$58 \quad$ The Natal Witness "Prison Reform" (29 December 1904).

59 The Natal Advertiser "Crime and the Criminal II" (18 September 1905).

60 The Natal Advertiser "Crime and the Criminal II" (18 September 1905).

$61 \quad$ The Natal Witness "Crime and the Criminal III" (20 September 1905).
} 
the error of his ways and began to cooperate completely with the authorities that he would be released:

The aim of the reformatory is to apply the principle of probation by making life within its walls a probationary life; a life in which this principle shall become incorporated in the very consciousness and soul of the offender. ${ }^{62}$

If indeterminate sentences were to be introduced, however, a number of changes would have to be made in the penal system of Natal. First, only "real" criminals (ie those who had shown their unfitness to be at large, and were thus in need of reformation) should be admitted to prison. Rose pointed out that many short-sentence prisoners were not "criminals" in the true sense of the word but were merely defined as "criminals" by the law. He protested against the "increasing number of acts, not criminal in themselves, which came under the designation of 'crime'". He stated that:

Legislatures are far too prone to define as crime practices which they desire to suppress, and to make them punishable by terms of imprisonment. ${ }^{63}$

In effect, Rose was saying that the prison should not be used merely as a means of social control. The prison had a far more important function since, like the school or the army, it should train, educate and reform its inhabitants. As an example of the misuse of the penal system, Rose pointed out that the breach of certain municipal laws was punishable by imprisonment. Such practices did not arise from a criminal instinct but were "absolutely legal until by legislation they [were] ... ranked as crimes". ${ }^{4}$ The solution to the problem was to replace short sentences with fines, which would ensure that only those in need of reform would enter prison. Rose admitted that this might not be practical in the case of "natives and Indians". 65

The second change required in the penal system of Natal if indeterminate sentences were to be introduced was the need for better trained and educated prison warders. Under the proposed system the warder would carry a great responsibility, since it would be his task to train and educate the prisoner and decide when that prisoner was reformed. The warders in Natal at this time were anything but refined and cultured men, able to show

62 The Natal Witness "Crime and the Criminal III" (20 September 1905).

63 The Natal Witness "Crime and the Criminal I" (13 September 1905).

64 The Natal Witness "Crime and the Criminal I" (13 September 1905).

65 The Natal Witness "Crime and the Criminal III" (20 September 1905). 
an erring individual the error of his ways! Rose ${ }^{66}$ stated that the introduction of his proposals:

... would demand the employment of a higher - at least a more cultured type of men in our prisons than, generally speaking, we have now.

\section{Role of shame and degradation in the punishment of white offenders, and the perceived ideological consequences of racial mixing in prisons for colonial society at large}

Underlying all of the proposals discussed in the previous section was the fundamental assumption that it was deeply undesirable to equate, in any way, the punishment of white and black offenders. The racist ideology which pervaded the thinking of Natal's white bourgeoisie at the turn of the century defined white prisoners as members of the white master class. The fact that they had committed crimes did not alter this fact. According to this twisted logic, white prisoners should be treated differently from black prisoners, who were seen as belonging to the black servant class. The consensus within white colonial society at the time was that white and black prisoners should be separated. ${ }^{67}$ The psychological effect of being confined together with black prisoners was thought to be harmful to white inmates, and the social stigma attached to being a white prisoner in colonial Natal was thought to be particularly severe. The racist attitudes of many white colonists led them to believe that white prisoners experienced particularly intense humiliation - not only because they were labelled as criminals, but also because they were placed on a par with black prisoners. In effect, it was believed that white prisoners suffered a "double humiliation" in the prisons of colonial Natal. ${ }^{68}$ It was believed that this "double humiliation" served to "degrade" and "harden" the white prisoners, which negatively affected their prospects

66 The Natal Witness "Crime and the Criminal III" (20 September 1905). Also see The Natal Witness "Prison Reform" (31 December 1904).

67 The "herding together" of black and white prisoners was characterised as a "grave defect in prison administration". See The Natal Advertiser "Industrial Prisons" (30 May 1904).

68

In 1904, for example, in a letter to The Natal Advertiser condemning the practice of marching white and black prisoners together through the streets, a prominent religious leader, Archdeacon Barker, explained that: "This must, I think, tend to harden them [i.e. the white prisoners]. I have often seen the white prisoners marching at the head of a long column of native prisoners, and have felt my face crimson with a feeling of shame, and I have seen the same prisoners upon being watched, hang their heads and blush for very shame - as much, perhaps, from their companionship as from their position." See The Natal Advertiser "Opinions of Representative Men Letter of Joseph Barker" (30 May 1904). 
of successful rehabilitation and reintegration into white society. ${ }^{69}$ The prevailing mood within white society in colonial Natal at the beginning of the twentieth century was summed up in an editorial in The Natal Advertiser published in June 1904 which condemned the "indiscriminate admixture" of races in Natal's prisons as "possibly one of the very worst features of our treatment of the prisoner at the present day". ${ }^{70}$

A direct consequence of the obsessive focus on race in the punishment of offenders - with better treatment reserved for "Europeans" - was that the definition of who qualified to be placed in the category "European" became vigorously contested. Complaints were heard from certain prisoners clearly those who considered themselves to be true "Europeans" - that prisoners of mixed race were able to pass themselves off as "Europeans" within the penal system of colonial Natal. ${ }^{71}$ The anxiety of white prisoners to avoid "contamination" by contact with prisoners of mixed race was at times almost paranoid. This is reflected in the following deeply racist account by a white journalist confined in the Durban Gaol at the turn of the century:

[A] European in Natal outside of a prison, means a white man with no coloured blood in him. Inside a prison it means anybody with a nominal education and

69 In 1904, for example, one white inmate imprisoned at the Central Gaol in Pietermaritzburg described his experience of stone breaking as follows: "All around him in barbed-wire cages, he sees specimens of every native tribe in South Africa performing the same labour. Most likely on either side he finds a dirty Hottentot or Griqua, clad in exactly the same dress, and treated in every respect on a par with himself. It is then that he realises the utter degradation to which he has sunk, and the iron begins to enter his soul." See The Natal Advertiser "Testimony from Within" (1 June 1904). Another example is found in the following extract published in The Natal Advertiser in 1905, condemning the mixing of races in prison labour gangs: "The white man and the Kafir are placed on the same level, they shovel stones, mix concrete, and push trucks along the rails together, and the moral level of the white man, instead of being raised by useful employment ... is ... reduced to one of the lowest planes of degeneration." See The Natal Advertiser "Prison Reform" (21 February 1905).

70 The Natal Advertiser "The Criminal Regenerate (Editorial)" (7 June 1904). The editorial went on to state that: "If any condition of life in our prisons is responsible for the turning out of a class of men who return immediately upon their release to their old pursuits that [i.e. the mixing of races in the prisons] undoubtedly is, for as it has been pointed out by chaplains and others who have had opportunities of watching the conduct of prisoners while in confinement, it affects the average [white] prisoner as a horrible degradation." See The Natal Advertiser "The Criminal Regenerate (Editorial)" (7 June 1904).

71 According to one correspondent to The Natal Advertiser: "Nothing is more keenly felt, nothing tends more to make a white man lose his self respect in effecting reformation than to be paraded cheek by jowl several times a day with, and addressed in terms of familiarity by sombre tinted individuals, who in this part of the world only pass muster as 'Europeans' ...". See The Natal Advertiser "Prison Reform" (5 January 1905). 
dressed something like a European... . [T]he idea of whites and blacks huddled together is, when you see it as I saw it in gaol, revolting .... Three in a little cell - think of it - with the same bucket of water from which to drink, the same bucket to use as a latrine, the same blankets continually interchanged, the same filth, and insect life creeping and crawling from white to black and from black to white! $!^{72}$

It was not only the perceived negative effects of racial mixing on white prisoners themselves - severe humiliation, increased levels of social stigma, a hardening of negative attitudes, and so on - which concerned the white public in colonial Natal at the turn of the century. The symbolic messages conveyed to society at large by the practice of confining white and black offenders together in the same prison were particularly worrying to the white ruling class. For the white colonists, any perception that white and black prisoners were regarded by the authorities as being in any way equal had to be avoided. After all, if prisoners of different races were equal, why not ordinary citizens of different races? Furthermore, any penal practice which might be perceived as an inversion of the traditional power relations between colonisers and colonised, between whites and blacks, and/or between masters and servants - for example, allowing black prison warders to exercise any type of authority over white prisoners - had to be avoided at all costs. ${ }^{73}$ The perceived danger of allowing penal policy to interfere in any way with traditional authority relationships between the white colonisers and their black colonial subjects was explicitly spelled out by the Natal Witness, as follows:

The indiscriminate mixing of whites and blacks is a matter which calls for urgent consideration if the respect of the black man for his white master is to be maintained; and our readers will agree that steps should be taken to separate the white and coloured races entirely during the period of incarceration. ${ }^{74}$

72 Hardy Black Peril 274-275.

73 For example, in 1904 a white inmate confined in a prison in Northern Natal stated as follows: "I consider that the way the white prisoners are treated is a disgrace to civilization. They are compelled to work side by side with Kafirs, while they must submit to the indignity of being ordered about the place by native constables." See The Natal Advertiser "Testimony from Within" (1 June 1904).

The Natal Advertiser "Testimony from Within" (1 June 1904). Another example of white ruling-class perceptions of the ideological dangers inherent in subjecting white prisoners to the authority of black prison guards, is found in the following extract from an editorial in The Natal Advertiser: "It does not take a very far-sighted person to see the possible results of that [i.e. the practice of placing black prison guards in charge of white prisoners] in the future, nor does it take a far-sighted person to see the gross misuses to which the custom is capable of being put by ignorant natives, who take a certain delight in making the white man feel their power for once in a way." See The Natal Advertiser "The Criminal Regenerate (Editorial)" (7 June 1904). 
Of particular concern to the white colonists at this time was that white prisoners be shielded completely from public view - specifically the view of the black public. In the minds of the white ruling class, it was anathema for representatives of the white master race - even if they were convicted offenders - to be seen in a position of subservience to, or under the authority of, representatives of the black indigenous population. This was even if such representatives of the indigenous population were duly appointed prison warders. Allowing black and white prisoners to be marched together through the streets of Pietermaritzburg from the gaol to the courthouse was condemned as a "public and official contravention of decency". ${ }^{75}$ In a searing editorial published in June 1904, the Natal Witness cautioned that the public would "not longer permit the degradation of Europeans before a black population", and enquired why no "Black Maria" - ie a police van for the transport of prisoners - had been provided "to keep white prisoners from the inquisitive gaze of the crowd". ${ }^{76}$ Clearly, on a broad ideological level, maintaining the authority relationship between the white colonial masters and their black colonised servants was uppermost in the minds of the white ruling class in colonial Natal at this time.

As a final point in relation to the perceived negative ideological consequences of allowing the punishment of white and black offenders to overlap, it is interesting to note the uniquely contested "in-between" position occupied by prisoners of mixed race. As stated earlier, the definition of "European" was not settled in colonial Natal. Prisoners who regarded themselves as "true Europeans" - ie as being racially pure - were quick to point out the negative ideological consequences of failing to distinguish between prisoners who were true "white men", and others who were members of some or other "coloured race":

\begin{abstract}
The gaols in Maritzburg and Durban see some thousands of natives passing through every year, and they observe that you treat white men (whom they naturally regard as your brothers) on an absolute equality with Hottentots, Griquas, and other coloured races, whom they themselves regard as their inferiors. ${ }^{77}$
\end{abstract}

\title{
7 Conclusion
}

Through an examination of the colonial discourse surrounding the incarceration of "European" prisoners within the Colony of Natal towards the end of the nineteenth and the beginning of the twentieth centuries, this 
article has shown that the punishment of this category of offenders raised all sorts of ideological problems for the white ruling class. The offenders in question were members of the white "master race". As such, the methods by which they were punished were bound to be highly symbolic. In terms of the racist ideology of many of Natal's white colonists, racially mixed prisons were seen as being unsuitable for a number of reasons. First, the white prisoner was seen as being psychologically degraded and as suffering a double humiliation, not only by being confined, but also by being confined alongside black prisoners, thereby suppressing his instinct to reform. Second, the authority of the white race as a whole was brought into contempt when white prisoners were seen by members of the black public to be in a position of subservience. Third, because of the intense social stigma attached to imprisonment, as well as the fact that all unskilled labour in colonial Natal was performed by the black inhabitants of the colony, white ex-prisoners without skills were unable to obtain employment upon leaving prison.

The above issues came to the fore in a public debate on the subject of prison reform, which was initiated by the Natal Witness in May 1904. The complete separation of white and black prisoners was urged, and the idea of a separate industrial prison for white offenders was raised. The proposed industrial prison would provide industrial training for white prisoners, which would enable them to find suitable employment upon discharge from prison. A system of indeterminate sentences would be instituted along with the programme of industrial training, and the reform of the white prisoner would be a major consideration. ${ }^{78}$ The public debate was eventually to lead to the appointment of the Prison Reform Commission of 1905-1906, which incorporated many of the ideas raised during the public debate in its final report.

In conclusion, it is submitted that the importance of the various views, opinions, suggestions and recommendations which formed part of the public debates traced in this article lies not so much in whether or not they were followed and adopted. Rather, their importance lies in the fact that they provide a clear picture of the nature and overall shape of the racist ideology which underpinned the punishment of offenders in colonial Natal. In many ways, perhaps, the racist ideas which dominated penal discourse in colonial Natal may be regarded as laying the foundation for the penal ideologies

78 See The Natal Advertiser "Crime and the Criminal IV" (25 September 1905) and The Natal Advertiser "Crime and the Criminal V" (27 September 1905). 
which characterised the notorious apartheid era, which dawned half a century after the events discussed in this article.

\section{Bibliography}

\section{Literature}

Bernault "Politics of Enclosure"

Bernault $\mathrm{F}$ "The Politics of Enclosure in Colonial and Post-Colonial Africa" in Bernault $\mathrm{F}$ (ed) A History of Prison and Confinement in Africa (Heinemann Portsmouth 2003) 1-53

Bundy Rise and Fall of the South African Peasantry

Bundy C The Rise and Fall of the South African Peasantry (University of California Press Berkeley 1979)

Crocker and Peté 2007 Obiter

Crocker A and Peté S "Letting go of the Lash: The Extraordinary Tenacity and Prolonged Decline of Judicial Corporal Punishment in Britain and its Former Colonies in Africa (Part 1)" 2007 Obiter 271-290

Greenberg Race and State in Capitalist Development Greenberg S Race and State in Capitalist Development - South Africa in Comparative Perspective (Ravan Press Johannesburg 1980)

Hardy Black Peril

Hardy GW The Black Peril (Holden \& Hardingham London 1914)

Ignatieff Just Measure of Pain

Ignatieff M A Just Measure of Pain (MacMillan London 1978)

Johnstone Class, Race and Gold

Johnstone FA Class, Race and Gold: A Study of Class Relations and Racial Discrimination in South Africa (Routledge \& Kegan Paul London 1976)

Killingray "Punishment to Fit the Crime?"

Killingray D "Punishment to Fit the Crime? Penal Policy and Practice in British Colonial Africa" in Bernault $\mathrm{F}$ (ed) A History of Prison and Confinement in Africa (Heinemann Portsmouth 2003) 97-118

Marks Reluctant Rebellion

Marks S Reluctant Rebellion: The 1906-1908 Disturbances in Natal (Clarendon Press Oxford 1970) 
Marks and Atmore Economy and Society in Pre-Industrial South Africa Marks S and Atmore A Economy and Society in Pre-Industrial South Africa (Longman London 1980)

Peté 1986 Natal U L \& Soc'y Rev

Peté $S$ "Punishment and Race: The Emergence of Racially Defined Punishment in Colonial Natal" 1986 Natal U L \& Soc'y Rev 99-114

Peté 1998 SAJHR

Peté S "To Smack or not to Smack? Should the Law Prohibit South African Parents from Imposing Corporal Punishment on their Children?" 1998 SAJHR 430-460

Peté "Brief History of Human Rights in the Prisons of Africa" Peté S "A Brief History of Human Rights in the Prisons of Africa" in Sarkin J (ed) Human Rights in African Prisons (HSRC Press Cape Town 2008) 4066

Peté and Devenish 2005 JSAS

Peté S and Devenish A "Flogging, Fear and Food: Punishment and Race in Colonial Natal" 2005 JSAS 3-21

Read "Kenya, Tanzania and Uganda"

Read JS "Kenya, Tanzania and Uganda" in Milner A (ed) African Penal Systems (Routledge \& Kegan Paul London 1969) 91-164

Riekert Natal Master and Servant Laws

Riekert JG The Natal Master and Servant Laws (LLM thesis University of Natal 1983)

Stanley Through the Dark Continent

Stanley HM Through the Dark Continent - The Sources of the Nile around the Great Lakes of Equatorial Africa and down the Livingstone River to the Atlantic Ocean (Sampson Low, Marston, Searle \& Rivington London 1878)

Welsh Roots of Segregation

Welsh DJ The Roots of Segregation: Native Policy in Colonial Natal 18451910 (Oxford University Press Oxford 1971)

\section{Official and archival documents}

Debates of the Legislative Council of the Colony of Natal 1883 vol 6 Debate of 24 August 1883: Mr Crowder 
Durban Corporation Superintendent of Police Report Book 6: Report of Superintendent, 26 April 1897

Durban Corporation Superintendent of Police Report Book 6: Report of Superintendent, 5 June 1902

Durban Corporation Superintendent of Police Report Book 7: Report of Superintendent, 5 December 1903

Durban Corporation Superintendent of Police Report Book 7: Report of Superintendent, 1 January 1904

GN 436 in Natal GG of 2 December 1884

GN 161 in Natal GG of 5 June 1888 (amended)

GN 344 in Natal Government Gazette of 5 June 1906

Master and Servants Ordinance Bill 9 of 1876

NAB CSO 314/2265

NAB CSO 982/3976

NAB CSO 1180/614

NAB CSO 1518/2324

NAB CSO 1518/4040

NAB CSO 1685/9488

NAB CSO 2847

Natal Blue Book 1896 at F44: Report of Governor Durban Gaol

\section{Newspaper articles}

The Natal Advertiser "A Plea for the Criminal" (30 May 1904)

The Natal Witness "Crime and the Criminal I" (13 September 1905)

The Natal Advertiser "Crime and the Criminal II" (18 September 1905)

The Natal Witness "Crime and the Criminal III" (20 September 1905) 
The Natal Advertiser "Crime and the Criminal IV" (25 September 1905)

The Natal Advertiser "Crime and the Criminal V" (27 September 1905)

The Natal Advertiser "Employment Bureau for Ex-Convicts" (3 June 1904)

The Natal Advertiser "Industrial Prisons" (30 May 1904)

The Natal Advertiser "Opinions of Representative Men - Letter of Joseph Barker" (30 May 1994)

The Natal Witness "Prison Reform II (Editorial)" (15 June 1904)

The Natal Witness "Prison Reform" (29 December 1904)

The Natal Witness "Prison Reform" (31 December 1904)

The Natal Advertiser "Prison Reform" (5 January 1905)

The Natal Advertiser "Prison Reform" (21 February 1905)

The Natal Advertiser "Testimony from Within" (1 June 1904)

The Natal Witness "The City Gaol" (6 May 1905)

The Natal Advertiser "The Criminal Regenerate (Editorial)" (7 June 1904)

The Natal Witness "Why Waste Prison Labour?" (8 June 1905)

\section{List of Abbreviations}

CSO

JSAS

NAB

SAJHR
Colonial Secretary's Office, Natal Journal of Southern African Studies

KwaZulu-Natal Archives Pietermaritzburg Repository

South African Journal on Human Rights 